\title{
Онтогенетические закономерности реализации устойчивости яровой пшеницы при действии абиотического стресса
}

\author{
() Л.В. Осипова ${ }^{1}$, И.В. Верниченко ${ }^{2}$, Т.Л. Курносова ${ }^{1}$, И.А. Быковская ${ }^{1}$, А.А. Лапушкина ${ }^{2}$ \\ ${ }^{1}$ ФГБНУ Всероссийский научно-исследовательский институт агрохимии \\ им. Д.Н. Прянишникова \\ 127550, Москва, ул. Прянишникова, 31а
}

${ }^{2}$ Российский государственный аграрный университет - МСХА им. К.А. Тимирязева 127550, Москва, ул. Тимирязевская, д. 49

E-mail: bykovskaya_irina@bk.ru

В вегетационном опыте оценивалось влияние предпосевная обработка семян (ПОС) биогенным элементом кремнием в онтогенезе яровой пшеницы в условиях стресса, вызванного повышенным содержанием алюминия в почве. Применение ПОС кремнием положительно влияло на продуктивность растений за счет снижения напряженности окислительного стресса и активации синтеза протекторных фотосинтетических пигментов, что, в свою очередь, уменьшало редукцию заложившихся элементов продуктивности.

Ключевые слова: яровая пшеница, кремний, предпосевная обработка семян, продуктивность, алюмокислотная токсичность, фоотосинтетические пигменты

Повышение устойчивости растений к стрессам - актуальная задача сельскохозяйственной науки, направленная на получение высоких и стабильных урожаев. Одним из наиболее распространенных стрессоров является алюминиевая токсичность ограничивающая продуктивность сельскохозяйственных культур. Симптомы алюминиевой токсичности проявляются в условиях кислых почв, занимающих от 40 до 50\% площадей пахотных земель в мире. Кислые почвы характеризуются многими неблагоприятными для роста растений свойствами (избыток $\mathrm{Mn}$ и $\mathrm{H}+$, недостаток фоссфора, кальция, магния и молибдена). Токсичность алюминия - ключевой фрактор, ограничивающий продуктивность сельскохозяйственных культур.

Проблема алюмокислотной токсичности решается классическим агрохимическим приемом - известкование почвы. Изучение механизмов токсичности алюминия необходимо для объективной оценки агрохимической перспективности сортов, для выведения новых устойчивых генотипов, усовершенствования теории неспецифической устойчивости растений к стрессам различной природы и разработки способов, оптимизирующих метаболизм при алюмокислотном стрессе.

По современным представлениям алюмоустойчивость является проявлением общей неспецифической устойчивости растений и связана со способностью растений в ответ на оксидативный стресс активизировать систему антиоксидантной защиты [1, 2]. Биогенный элемент кремний является её активным элементом, связывающим алюминий в малотоксичные соединения.

В связи с этим изучали физиолого-биохимические закономерности формирования продуктивности ярово при ПОС кремнием в условиях алюмокислотного стресса. 
Вегетационные эксперименты проводили в почвенной культуре по методике Журбицкого [3] на дерново-подзолистой среднесуглинистой почве со следующей агрохимической характеристикой: мин. = 16 мг/кг, Р2О5 93 мг/кг, К2О 82 мг/кг; Нг = 4,2 мг-экв. /100 г почвы; $S=12,0$ мг-экв. /100 г почвы. Питательные вещества вносили при закладке опытов, создавая фон питания - N50(PK)100. В опытные варианты вносили алюминий в дозе 150 мг/кг почвы.

Почву, кроме вариантов с алюминием, известковали по полной норме гидролитической кислотности. В течение вегетации поддерживали оптимальный уровень водообеспеченности - 70\%ПВ.

В настоящей работе опыты проводились с яровой пшеницей (Tríticum vulgare L.) сорта Лиза.

Перед посевом семена обрабатывали раствором силиката натрия (Na2SiO3 - 0,15\%). Растворы для обработки семян во всех вариантах брали в количестве равном $5 \%$ от массы семян.

В проведенных экспериментах определяли физиолого-биохимические показатели: редокс-статус, по интенсивности процессов перекисного окисления липидов (ПОЛ) и содержание фотосинтетических пигментов в онтогенезе растений.

В результате проведенных исследований установлено, что повышенное содержание алюминия в почве приводило к развитию окислительного стресса, из-за усиления генерации активных фрорм кислорода (АФК) (рис. 1). Кремний повышает устойчивость к алюминию, участвуя в образовании комплексов с органическими кислотами, снижая, таким образом, его негативное воздействие.

В проведенном эксперименте ПОС кремнием защищала растения пшеницы от оксидативного стресса, индуцированного алюминием, о чем свидетельствуют более низкие по сравнению с контролем значения концентрации МДА (рис. 1).

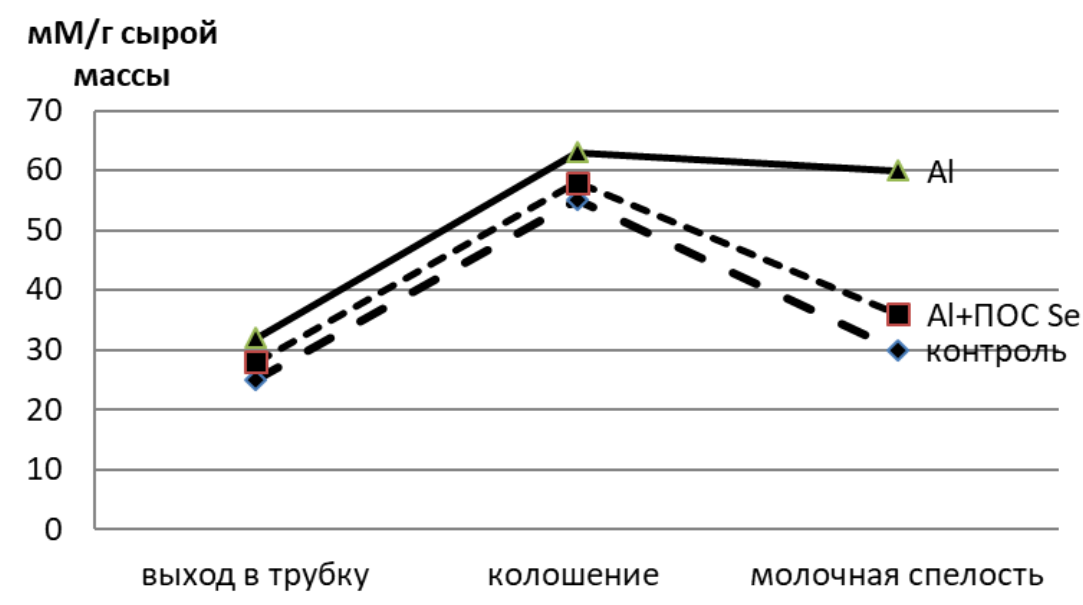

Рис. 1. Содержание МДА в онтогенезе пшеницы, ммоль/г сырой массы

В проведенном эксперименте были отмечены определенные закономерности в содержании фотосинтетических пигментов в онтогенезе яровой пшеницы при действии алюминия в зависимости от ПОС кремнием. 
Было установлено, что биосинтез пигментов в верхних листьях яровой пшеницы наиболее интенсивно идет в фразу колошения-цветения (рис. 1а). Это могло быть связано с дополнительной потребностью в ассимилятах. Кроме того, подробный анализ пигментного комплекса показал, что это увеличение обусловлено возрастанием содержания хлорофилла b (рис. 1б). В последние годы было показано, что кроме выполнения основной фотосинтетической функции хлорофилл b является регулятором развития растений и обеспечивает своевременный переход к закладке генеративных структур, цветению, и вызреванию семян $[4,5]$. В период цветения отмечено увеличение содержания хлорофрилла b более чем в 2 раза, которое снижалось после его окончания. Аналогичным образом изменялось и содержание каротиноидов, которые входят в систему фоотозащиты растений (рис. 2в).
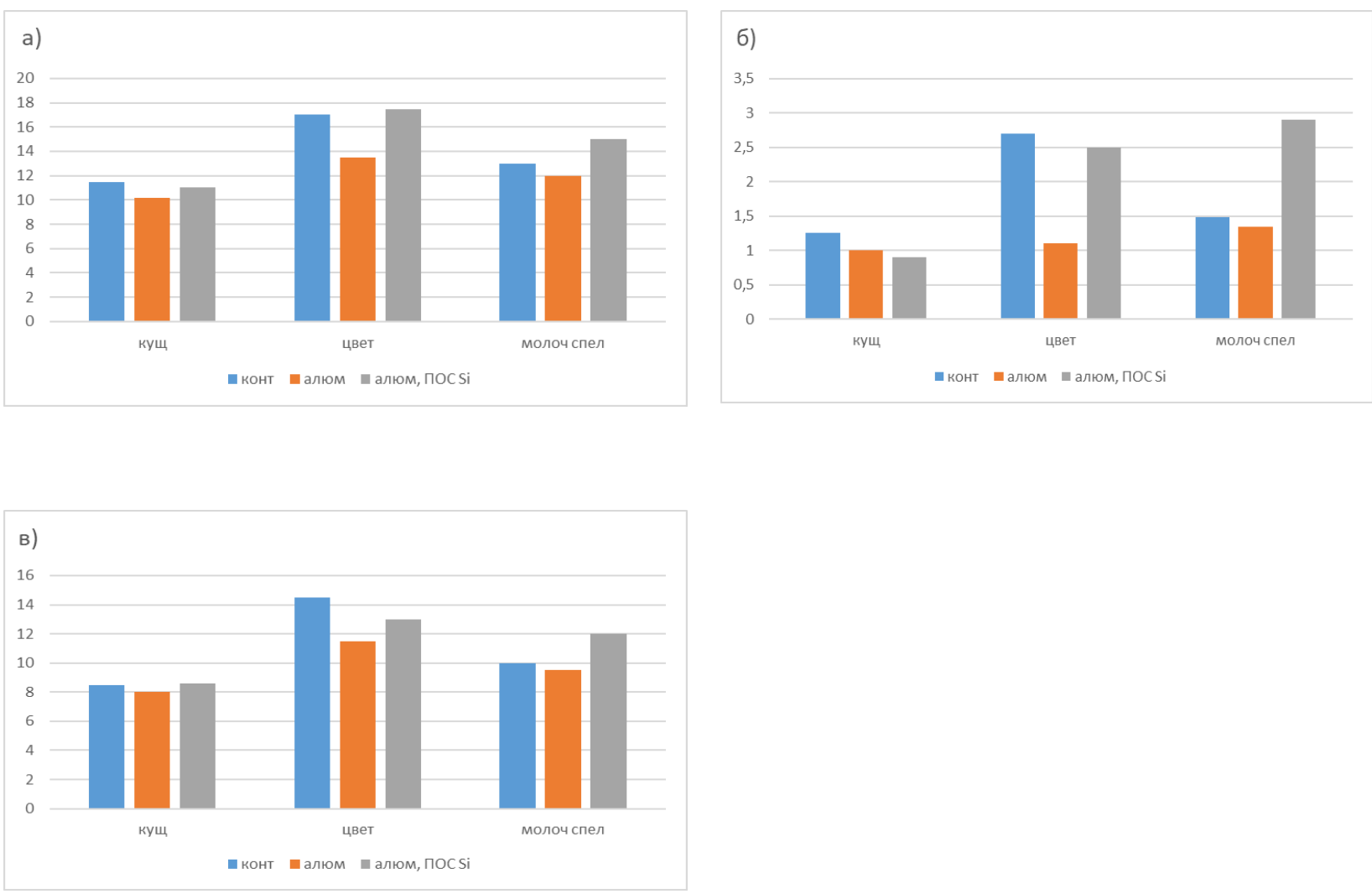

Рис. 2. Содержание пигментов в онтогенезе пшеницы, мг/г сырой массы а) общее содержание пигментов (хлорофиллы a, b; каротиноиды);

б) содержание хлорофилла b;

в) содержание каротиноидов

Наряду с фризиолого-биохимической реакцией растений на стресс отмечено и его влияние на морфогенетические процессы: формирование габитуса, закладку элементов зачаточного колоса, урожай пшеницы и его структуру.

Было установлено, что алюминий оказывал негативное воздействие на продуктивность пшеницы в контрольном варианте, депрессия продуктивности составляла $80 \%$, что было обусловлено уменьшением продуктивного кущения (35\%), озерненности колоса (77\%) и массы 1000 зерен (9\%) (табл. 2). 
Таблица 2. Продуктивность и структура продуктивности яровой пшеницы

\begin{tabular}{|l|c|c|c|c|c|c|c|c|}
\hline \multirow{2}{*}{ пОс } & \multicolumn{2}{|c|}{$\begin{array}{c}\text { Масса зерна, } \\
\text { г/растение }\end{array}$} & \multicolumn{2}{|c|}{$\begin{array}{c}\text { Продуктивная ку- } \\
\text { стистость }\end{array}$} & \multicolumn{2}{c|}{$\begin{array}{c}\text { Число зерен в } \\
\text { колосе, шт. }\end{array}$} & \multicolumn{2}{c|}{$\begin{array}{c}\text { Масса } 1000 \text { зе- } \\
\text { рен, г }\end{array}$} \\
\cline { 2 - 9 } & контроль & $\mathrm{Al}$ & контроль & $\mathrm{Al}$ & контроль & $\mathrm{Al}$ & контроль & $\mathrm{Al}$ \\
\hline $\mathrm{H} \mathrm{H}_{2}$ & 0,77 & 0,14 & 1,8 & 1,1 & 19,4 & 4,4 & 39,4 & 35,5 \\
\hline $\mathrm{Si}$ & 0,82 & 0,29 & 1,6 & 1,2 & 18,0 & 6,2 & 44,4 & 34,9 \\
\hline $\mathrm{HCP}_{0,5}$ & 0,05 & - & & & & 0,26 & & - \\
\hline
\end{tabular}

Предпосевная обработка семян кремнием оказала протекторное действие на элементы продуктивности, озерненность колоса и массу зерна с растения, снизилась депрессия кущения.

Защитное действие кремния было связано со снижением сброса заложившихся цветков на конусе нарастания главного побега, что обеспечило большую озерненность колоса и продуктивность всего растения.

Установлено, что повышенное содержание алюминия в почве приводило к развитию окислительного стресса, вызывающего изменения физиолого-биохимического статуса растений в онтогенезе пшеницы и снижение зерновой продуктивности. Применение кремния в виде предпосевной обработки семян активизировало синтез фоотосинтетических протекторных пигментов - хлорофрилла b и каротиноидов в критический период формирования генеративных органов, снижала напряженность оксидативного стресса, оцениваемого по накоплению малонового диальдегида, уменьшало редукцию заложившихся цветковых зачатков, обеспечивая меньшую депрессию зерновой продуктивности по сравнению с необработанным контролем.

\section{Литература}

1. Filiz Vardar F., Unal M. Aluminum toxicity and resistance in higher plants//Advances in Molecular Biology. 2007 - n.1.- P. 1-12.

2. Лисицын Е.М., Амунова О.С. Сравнительная алюмоустойчивость сортов яровой пшеницы, выведенных в Сибири и Европейской части России // Аграрная наука ЕвроСеверо-Востока. - 2014. - № 5 (42). - С. 4-9.

3. Журбицкий 3.И. Теория и практика вегетационного метода. - М.: Наука, 1968. - 266 с.

4. Жученко А.А. Фундаментальные и прикладные научные приоритеты адаптивной интенсификации растениеводства в XXI в. - Саратов: ООО «Новая газета». - 2000. - 275 C.

5. Осипова Л.В., Курносова Т.Л., Быковская И.А. Повышение адаптивного потенциала ячменя ярового (Hordeum vulgare L.) при действии абиотического стресса // Проблемы агрохимии и экологии. - 2016. - № 3. - С. 48-51. 
Ontogenetic patterns of implementation of spring wheat resistance under action of abiotic stress

L.V. Osipova ${ }^{1}$, I.V. Vernichenko ${ }^{2}$, T.L. Kurnosova ${ }^{1}$, I.A. Bykovskaja ${ }^{1^{*}}$, A. A. Lapushkina ${ }^{2}$

${ }^{1}$ Pryanishnikov Research Institute of Agricultural Chemistry, Federal Agency Research Organization,

ul. Pryanishnikova 31a, Moscow, 127550, Russia;

${ }^{2}$ Russian State Agrarian University - Moscow Timiryazev Agricultural Academy ul. Timiryazevskay, 49, Moscow, 127550, Russia

*bykovskaya_irina@bk.ru

In the vegetation experiment, the influence of pre-treatment of seeds (PIC) with a biogenic element with silicon in the ontogenesis of spring barley under conditions of stress caused by increased aluminum content in the soil was evaluated. The use of PIC silicon positively affected plant productivity by reducing oxidative stress and activating the synthesis of protective photosynthetic pigments, which, in turn, reduced the reduction of embedded productivity elements.

Keywords: spring wheat, silicon, pre-treatment of seeds, productivity, aluminium acid toxicity, photosynthetic pigments 